\title{
DOCK8 wt Allele
}

National Cancer Institute

\section{Source}

National Cancer Institute. DOCK8 wt Allele. NCI Thesaurus. Code C116054.

Human DOCK8 wild-type allele is located in the vicinity of 9p24.3 and is approximately $250 \mathrm{~kb}$ in length. This allele, which encodes dedicator of cytokinesis protein 8, may be involved in the activation of small GT Pases. Variation in the gene is associated with autosomal recessive hyperimmunog lobulin $\mathrm{E}$ recurrent infection syndrome and disruption or deletion of the gene is associated with autosomal dominant mental retardation 2. 